九州大学学術情報リポジトリ

Kyushu University Institutional Repository

\title{
Changes in Fatty Acid Composition of Membrane Fractions during Hardening of Chlorella ellipsoidea
}

\section{Kabata, Kiyotaka}

Laboratory of Food Hygienic Chemistry, Faculty of Agriculture, Kyushu University

Sadakane, Haruo

Laboratory of Food Hygienic Chemistry, Faculty of Agriculture, Kyushu University

Kurose, Masumi

Laboratory of Food Hygienic Chemistry, Faculty of Agriculture, Kyushu University

Kobayakawa, Akihiko

Laboratory of Food Hygienic Chemistry, Faculty of Agriculture, Kyushu University

他

https://doi.org/10.5109/23722

出版情報: 九州大学大学院農学研究院紀要. 25 (2/3)，pp.91-97，1980-11. Kyushu University バージョン：

権利関係: 
J. Fac. Agr., Kyushu Univ., 25 (2 • 3) 91-97 (1980)

\title{
Changes in Fatty Acid Composition of Membrane Fractions during Hardening of Chlorella ellipsoidea*
}

\author{
Kiyotaka Kabata, Haruo Sadakane, Masumi Kurose**, \\ Akihiko Kobayakawa***, Tadao Watanabe and Shoji Hatano \\ Laboratory of Food Hygienic Chemistry, Faculty of Agriculture, \\ Kyushu University 46-09, Fukuoka 812
}

(Received June 26, 1980)

\begin{abstract}
Chlorella ellipsondea cells at an intermediate stage in the ripening phase of the cell cycle were hardened at $3^{\circ} \mathrm{C}$ for $48 \mathrm{hr}$. Chloroplast and E. R. fractions were prepared from the homogenate of Chlorella cells on sucrose density gradients. Changes in fatty acid composition of chloroplast and E. R. fractions and whole cells during the development of frost hardiness were determined by gas-liquid chromatography. In whole cells and chloroplast fraction, myristic, palmitic and linoleic acids decreased while oleic and linolenic acids increased. In E. R. fraction, myristic, palmitic, oleic and linoleic acids decreased while linolenic acids increased. The percentage of unsaturated fatty acid increased during hardening from $70.1 \%$ to $80.5 \%$ in chloroplast fraction, from $70.4 \%$ to $78.0 \%$ in E. R. fraction and from $73.6 \%$ to $81.5 \%$ in whole cells. The increase in unsaturation was mainly due to the increase in linolenic acid.
\end{abstract}

\section{INTRODUCTION}

Recent papers suggest that some profound membrane changes are involved in the development of frost hardiness (Garber and Steponkus, 1976; Steponkus et al., 1977; Yoshida, 1976). Since lipids are essential component of membranes, lipid changes during hardening of higher plants have been studied intensively (Gerloff et al., 1966; Willemot et al., 1977). Particularly, a preferential synthesis of unsaturated fatty acids during hardening has been reported (de la Roche et al., 1972; Grenier and Willemot, 1974; de la Roche et al., 1975). In young shoots of wheat and rye an increase in linolenic acid was observed, while in alfalfa roots the proportion of linoleic acid increased (de la Roche et al., 1972; Grenier and Willemot, 1974; de la Roche et al., 1975). Willemot(1977) indicated that low temperature stimulation of linolenic acid synthesis was a prerequisite for the development of freezing resistance in wheat. However, de la

\footnotetext{
* Studies on frost hardiness in Chlorella ellipsoidea Part VII.

** Present address: Higashichikushi Women's Junior College, Kitakyushu-shi.

*** Present address: Fujiya Co. Ltd., Tokyo.
}

\section{ABBREVIATION}

E. R. : endoplasmic reticulum; DPCO : diphenylcarbazone; DCIP: 2,6-dichlorophenolindophenol; DCMU: 3-(3,4-dichlorophenyl)-1,1-dimethylurea. 
Roche (1979) demonstrated that an enrichment in linolenic acid is not a prerequisite for low temperature acclimation in wheat. The question arises whether an increase in fatty acid unsaturation is a prerequisite for the development of frost hardiness in plant or not.

Previous studies have shown that hardened cells of Chlorella ellipsoidea are able to survive slow freezing to $-196^{\circ} \mathrm{C}$ (Hatano et al., $1976 \mathrm{a}, \mathrm{b}$ ) and that amounts of glycolipids, phospholipids and the nonpolar lipid in the cells increase with an increase in the algal hardiness (Kabata et al., 1979).

As a first step in studying the necessity of an increase in fatty acid unsaturation for the development of frost hardiness, changes in fatty acid composition were determined in chloroplast and E. R. fractions and whole cells during hardening of Chlorella ellipsoidea.

\section{MATERIALS AND METHODS}

\section{Plant materials}

Chlorella ellipsoidea Gerneck (IAM C-27) was grown in synchronous culture at $25^{\circ} \mathrm{C}$, under 9-10 $\mathrm{Klx}$, with $1 \% \mathrm{CO}$,-air, and a 28 -hr light-14-hr dark regime as described previously (Hatano et al., 1976 a). Since the cells were most hardened at the $L_{2}$ stage (an intermediate stage in the ripening phase of the cell cycle), $\mathrm{L}_{2}$ cells were used in this study.

\section{Hardening}

Algal cells synchronized at $25^{\circ} \mathrm{C}$ were directly hardened at $3^{\circ} \mathrm{C}$ for $48 \mathrm{hr}$. During treatment, the culture was aerated with air enriched to about $1 \% \mathrm{CO}_{2}$ and kept in the light $(9-10 \mathrm{Klx})$ as described previously (Hatano et al., 1976a).

\section{Determination of viability}

The viability of algal cells was determined with the growth curve on the basis of $\mathrm{A}_{420}$. Previous study has demonstrated that the viability determined with the growth curve coincided with that determined by both colony count and packed cell volume.

\section{Sucrose gradient centrifugation}

About $5 \times 10^{9}$ cells of the algae were suspended in $7.5 \mathrm{ml}$ of $0.05 \mathrm{M}$ phosphate buffer ( $\mathrm{pH} 7.8$ ) containing $0.4 \mathrm{M}$ sucrose and $0.01 \mathrm{M} \mathrm{NaCl}$. The suspension was homogenized with glass beads of $0.5 \mathrm{~mm}$ diameter in a reciprocal shaker, Vibrogen-Zellmtihle (Edmund Bühler Co., Tübingen, Germany), at 4,500 rpm at $3^{\circ} \mathrm{C}$ for $10 \mathrm{~min}$ in unhardened cells and for $6 \mathrm{~min}$ in hardened cells. The rate of disrupted cells was about 80-90 $\%$ in unhardened and hardened cells. The homogenate was centrifuged at $200 \times \mathrm{g}$ for $10 \mathrm{~min}$ to remove the glass beads, whole cells and cell debris. The supernatant was centrifuged at $9,000 \times \mathrm{g}$ for $30 \mathrm{~min}$ at $4^{\circ} \mathrm{C}$.

The supernatant obtained by centrifugation at $9,000 \times \mathrm{g}$ was diluted twice with $0.05 \mathrm{M}$ phosphate buffer $(\mathrm{pH} 7.8)$ containing $0.01 \mathrm{M} \mathrm{NaCl}$ and centrifuged at $105,000 \times \mathrm{g}$ for $1 \mathrm{hr}$ at $4^{\circ} \mathrm{C}$ in an RP 50-2 rotor with a Hitachi $55 \mathrm{P}-2$ ultracentrifuge. The precipitate was used as E. R. fraction. 
The pellet obtained by centrifugation at 9, OOOxg was resuspended in 0.9 $\mathrm{ml}$ of $0.05 \mathrm{M}$ phosphate buffer ( $\mathrm{pH} 7.8$ ) containing $0.4 \mathrm{M}$ sucrose and $0.01 \mathrm{M} \mathrm{NaCl}$. The suspension $(0.3 \mathrm{ml})$ was loaded onto a discontinuous sucrose gradient. Discontinuous sucrose gradients were prepared by layering in succession $1 \mathrm{ml}$ each of 1 . OM, $1.5 \mathrm{M}, 2$. OM and $2.5 \mathrm{M}$ sucrose solution in $0.05 \mathrm{M}$ phosphate buffer ( $\mathrm{pH} 7.8$ ) containing $0.01 \mathrm{MNaCl}$. The gradients were centrifuged at $64,000 \times \mathrm{g}$ for $1.5 \mathrm{hr}$ at $4^{\circ} \mathrm{C}$ in a Hitachi RPS-50 rotor. After centrifugation, each fraction was collected for subsequent photochemical activity assays.

\section{Measurements of photochemical activities}

Photosystem I activity was measured by DPCO disproportionation at $487 \mathrm{~nm}$ according to the method described by Vernon (1972). The reaction mixture (3 ml) contained $50 \mathrm{mM}$ phosphate buffer ( $\mathrm{pH}$ 7. 8),2.5 mM DPCO, $10 \mu \mathrm{M}$ DCMU and chloroplasts (30 $\mu \mathrm{g}$ chlorophyll). Photosystem II activity was measured by DCIP photoreduction at $610 \mathrm{~nm}$ according to the method described by Hirayama and Matui (1976). The reaction mixture $(3 \mathrm{ml})$ contained $50 \mathrm{mM}$ Tris $-\mathrm{HCl}(\mathrm{pH}$ 8. 0), $0.1 \mathrm{mM}$ DCIP, $10 \mathrm{mM} \mathrm{NaCl}$ and chloroplasts (30 $\mathrm{gg}$ chlorophyll). Chlorophyll was measured by the method of Mackinney (1941).

\section{Lipid extraction and fatty acid assay}

Total lipids were extracted from chloroplast and E. R. fractions and whole cells and the nonlipid contaminants were removed as previously reported (Kabata et al., 1979). Fatty acid composition of each extract was determined by gas chromatography of the methyl esters. Methanolysis of fatty acids was performed according to the method of Stoffel et al. (1959) with a slight modification. After cooling, the methyl ester samples were extracted with n-hexane and chromatographed on a Hitachi model K53 equipped with a hydrogen flame ionization detector at $0.7 \mathrm{~kg} / \mathrm{cm}^{2} \mathrm{~N}_{2}$ flow. The column $(1 \mathrm{~m} \times 3 \mathrm{~mm})$ was packed with $15 \%$ ethylene glycol succinate polyester (80/100 mesh). The column temperature was programmed from 180 to $230^{\circ} \mathrm{C}$ at a rate of $5^{\circ} \mathrm{C} / \mathrm{min}$.

\section{RESULTS AND DISCUSSION}

The membrane fragments of chloroplasts in unhardened and hardened cells obtained by centrifugation at 9, OOOxg were subdivided into fractions 1,2 and 3 by discontinuous sucrose gradient centrifugation at 64 , OOOxg, as shown in Fig. 1. The volume of fraction 1 in hardened cells was more than that in unhardened cells, while the volumes of fractions 2 and 3 in hardened cells were less than those in unhardened cells. These results suggest that a specific gravity of membrane fragments decrease during the development of the algal hardiness.

Tables 1 and 2 show photochemical activities of three fractions in the 9, OOOxg pellet of unhardened and hardened cells, respectively. In both photosystem I and II activities, fraction 1 showed higher values than fractions 2 and 3. Therefore, fraction 1 was used as chloroplast fraction to assay the fatty acid composition of chloroplast membranes. However, the $\mathrm{O}_{2}$-uptakeac- 


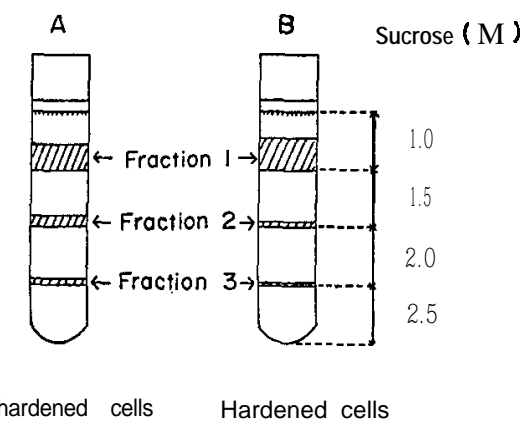

Fig. 1. Profile of fractions, on discontinuous sucrose gradient, obtained after disruption of Chlorella cells.

Table 1. Photochemical activities of three fractions in the $9,000 \times \mathrm{g}$ pellet of unhardened cells.

Photosystem I activity Photosystem II activity (DPCO reacting) (DCIP reduced)

\begin{tabular}{llll}
\hline & & $\mu$ moles $/ \mathrm{mg} \mathrm{chl} / \mathrm{hr}$ & \\
Fraction & 1 & 292 & 41 \\
Fraction & 2 & 217 & 38 \\
Fraction & 3 & 206 & 28 \\
\hline
\end{tabular}

Table 2. Photochemical activities of three fractions in the $9,000 \times \mathrm{g}$ pellet of hardened cells.

\begin{tabular}{|c|c|c|}
\hline & $\begin{array}{l}\text { Photosystem I activity } \\
\text { (DPCO reacting) }\end{array}$ & $\begin{array}{l}\text { Photosystem II activity } \\
\text { (DCIP reduced) }\end{array}$ \\
\hline & \multicolumn{2}{|c|}{$\mu \mathrm{moles} / \mathrm{mg} \mathrm{chl} . / \mathrm{hr}$} \\
\hline Fraction 1 & 307 & 46 \\
\hline Fraction 2 & 221 & 39 \\
\hline Fraction 3 & - & - \\
\hline
\end{tabular}

tivity and cytochrome c oxidase activity were widespread in sucrose gradient solutions in both unhardened and hardened cells (data not shown). Fraction 1 contains some of mitochondria.

Table 3 shows the fatty acid composition of total lipids from unhardened and hardened cells. In Chlorella ellipsoidea, palmitic, oleic and linolenic acids were the major constituents of fatty acids. During hardening, myristic, palmit. ic and linoleic acids decreased while oleic and linolenic acids increased. The percentage of unsaturated fatty acid increased from $73.6 \%$ to $81.5 \%$ during hardening. The increase in unsaturation was due to oleic and linolenic acids.

Table 4 shows the fatty acid composition of chloroplast fraction from unhardened and hardened cells. In chloroplast fraction, myristic, palmitic and linoleic acids decreased while oleic and linolenic acids increased during hardening. The percentage of unsaturated fatty acid increased from $70.1 \%$ to $80.5 \%$ during hardening. The increase in unsaturation was mainly due to the 
Table 3. Relative fatty acid composition of unhardened and hardened cells. Relative percent: mean value with standard error $(n=3)$.

\begin{tabular}{ccc}
\hline \multirow{2}{*}{ Fatty acid } & \multicolumn{2}{c}{ Relative percent of fatty acid content } \\
\cline { 2 - 3 } & Unhardened cells & Hardened cells \\
\hline $14: 0$ & $2.5 \pm 0.15$ & $0.7 \pm 0.03^{\prime \prime}$ \\
$16: 0$ & $23.7 \pm 0.18$ & $17.7 \pm 0.26^{*}$ \\
$18: 0$ & $0.2 \pm 0.03$ & $0.1 \pm 0.03$ \\
$18: 1$ & $26.6 \pm 0.20$ & $33.6 \pm 0.49^{*}$ \\
$18: 3$ & $12.7 \pm 0.33$ & $8.4 \pm 0.12^{*}$ \\
Saturated \% & $34.3 \pm 0.20$ & $39.4 \pm 0.23^{*}$ \\
Polyunsaturated \% & $26.4 \pm 0.28$ & $18.5 \pm 0.21^{*}$ \\
\hline
\end{tabular}

$(* \mathrm{P}<0.001)$

Table 4. Relative fatty acid composition of chloroplast fraction from unhardened and hardened cells. Relative percent: mean value with standard error $(n=3)$.

\begin{tabular}{ccc}
\hline & \multicolumn{2}{c}{ Relative percent of fatty acid content } \\
\cline { 2 - 3 } Fatty acid & Unhardened cells & Hardened cells \\
& $7.8 \pm 0.15$ & $2.5 \pm 0.10^{\prime \prime}$ \\
$14: 0$ & $21.6 \pm 0.16$ & $16.9 \pm 0.26^{*}$ \\
$18: 0$ & $0.6 \pm 0.05$ & $0.2 \pm 0.03^{*}$ \\
$18: 1$ & $34.3 \pm 0.21$ & $35.7 \pm 0.32^{* * *}$ \\
$18: 2$ & $7.6 \pm 0.10$ & $6.2 \pm 0.35^{* * *}$ \\
18 & $28.1 \pm 0.18$ & $38.6 \pm 0.46^{*}$ \\
Saturated $\%$ & $29.9 \pm 0.21$ & $19.5 \pm 0.31^{*}$ \\
Polyunsaturated $\%$ & $70.1 \pm 0.25$ & $80.5 \pm 0.42^{*}$ \\
\hline
\end{tabular}

$(* \mathrm{P}<0.001 . \quad * * * \mathrm{P}<0.05)$

linolenic acid. Peoples et al. (1978) reported the hypothesis that the photosynthetic response is influenced by the unsaturated fatty acid composition of the chloroplast membrane which affect temperature-induced phase changes in chloroplast membrane lipids in alfalfa. The results in Table 4 support the hypothesis.

Table 5 shows the fatty acid composition of E. R. fraction from unhardened and hardened cells. During hardening, linolenic acid increased but myristic, palmitic, oleic and linoleic acids decreased. The difference in fatty acid composition between chloroplast fraction and E. R. fraction suggests that the fatty acid composition of cellular membrane for freezing tolerance differs in organelles. The percentage of unsaturated fatty acid increased from $70.4 \%$ to $78.0 \%$ during hardening. The large increase in linolenic acid contributed toward changing the composition of membrane lipids in Chlorella ellipsoidea. These results suggest that the increase in fatty acid unsaturation due to linolenic acid plays an important role in the hardening process.

Willemot (1977) indicated that low temperature stimulation of linolenic acid synthesis was a prerequisite for the development of freezing resistance in wheat. 
Table 5. Relative fatty acid composition of E. R. fraction from unhardened and hardened cells. Relative percent: mean value with standard error $(n=3)$.

\begin{tabular}{ccc}
\hline \multirow{2}{*}{ Fatty acid } & \multicolumn{2}{c}{ Relative percent of fatty acid content } \\
\cline { 2 - 3 } & Unhardened cells & Hardened cells \\
\cline { 2 - 3 } $14: 0$ & $4.0 \pm 0.10$ & $1.6 \pm 0.29 * *$ \\
$16: 0$ & $25.5 \pm 0.25$ & $20.1 \pm 0.28^{*}$ \\
$18: 0$ & $0.2 \pm 0.05$ & $0.3 \pm 0.06$ \\
$18: 2$ & $41.7 \pm 0.35$ & $32.2 \pm 0.72^{*}$ \\
$18: 3$ & $10.0 \pm 0.20$ & $9.4 \pm 0.12^{* * *}$ \\
Saturated 96 & $18.6 \pm 0.26$ & $36.4 \pm 0.90^{*}$ \\
Polyunsaturated $\%$ & $29.6 \pm 0.25$ & $22.0 \pm 0.32^{*}$ \\
\hline
\end{tabular}

(*P<0.001.** $\mathrm{P}<0.01$, *** $\mathrm{P}<0.05)$

However, de la Roche (1979) demonstrated that an enrichment in linolenic acid is not a prerequisite for low temperature acclimation in wheat. Their experimental conditions differ from each other. Willemot (1977) hardened winter wheat (Triticum aestivum) in an 8-hr light-16-hr dark regime while de la Roche (1979) in the dark. At present, we can not determine whether an increase in fatty acid unsaturation is the necessity for the development of frost hardiness in Chlorella. A previous study demonstrated that Chlorella cells are also hardened in the dark in the presence of $0.1 \%$ glucose (Hatano et al., 1978). Comparative studies between the hardening process in the dark and light are required to elucidate the necessity of an increase in fatty acid unsaturation for the development of frost hardiness.

\section{REFERENCES}

de la Roche, I. A. 1979 Increase in linolenic acid is not a prerequisite for development of freezing tolerance in wheat. Plant Physiol., 63: 5-8

de la Roche, I. A., C. J. Andrews and M. K. Pomeroy 1972 Lipid changes in winter wheat seedlings (Triticumaestivum) at temperatures inducing cold hardiness. Canad.J. Bot., 50: 2401-2409

de la Roche, I. A., M. K. Pomeroy and C. J. Andrews 1975 Changes in fatty acid composition in wheat cultivars of contrasting hardiness. Cryobiology, 12: 506-512

Garber, M. P. and P. L. Steponkus 1976 Alterations in chloroplasts thylakoids during cold acclimation. Plant Physiol., 57: 681-686

Gerloff, E. D., T. Richardson and M. A. Stahman 1966 Changes in fatty acids of alfalfa roots during cold hardening. Plant Physiol., 41: 1280-1284

Grenier, G. and C. Willemot 1974 Lipid changes in roots of frost hardy and less hardy alfalfa varieties under hardening conditions. Cryobiology, 11: 324-331

Hatano, S., H. Sadakane, J. Nagayama and T. Watanabe 1978 Studies on frost hardiness in Chlorella ellipsoidea III. Changes in 0, uptake and evolution during hardening and after freeze-thawing. Plant \& Cell Physiol., 19: 917-926

Hatano, S., H. Sadakane, M. Tutumi and T. Watanabe 1976 a Studies on frost hardiness in Chlorella ellipsoidea I. Development of frost hardiness of Chlorella ellipsoidea in synchronous culture. Plant \& Cell Physiol., 17: 451-458 
Hatano, S., H. Sadakane, M. Tutumi and T. Watanabe 1976 b Studies on frost hardiness in Chlorella ellipsoidea II. Effects of inhibitors of RNA and protein synthesis and surfactants on the process of hardening. Plant \& Cell Physiol., 17 : 643-651

Hirayama, 0. and T. Matui 1976 Effects of lipolytic enzymes on the photochemical activities of spinach chloroplasts. Biochimica et Biophysica Acta, 423: 540-547

Kabata, K., H. Sadakane, M. Miyachi, K. Nagata, S. Hatano and T. Watanabe 1979 Studies on lipid changes during the development of frost hardiness in Chlorella ellipsoidea. J. Fac. Agr., Kyushu Univ.. 23: 155-161

Mackinney. G. 1941 Absorption of light by chlorophyll solutions. J. Biol. Chem., 140: 315322

Peoples, T. R., D. W. Koch and S. C. Smith 1978 Relationship between chloroplast membrane fatty acid composition and photosynthetic response to a chilling temperature in four alfalfa cultivars. Plant Physiol., 61: 472-473

Steponkus, P. L., M. P. Garber, S. P. Myers and R. D. Lineberger 1977 Effects of cold acclimation and freezing on structure and function of chloroplast thylakoids. Cryobiology, 14: 303-321

Stoffel, W., F. Chu and E. H. Ahrews 1959 Analysis of long-chain fatty acids by gasliquid chromatography. Anal. Chem., 31: 307-308

Vernon, L. P. 1972 Diphenylcarbazone: A reagent for photosystem I activity in chloroplast fragments. Plant Physiol., 49: 862-863

Willemot, C. 1977 Simultaneous inhibition of linolenic acid synthesis in winter wheat roots and frost hardening by BASF 13338. a derivative of pyridazinone. Plant Physiol., 60: $1-4$

Willemot, C., H. J. Hope, R. J. Williams and R. Michaud 1977 Changes in fatty acid composition of winter wheat during frost hardening. Cryobiology, 14: 87-93

Yoshida, S. 1976 Changes in microsomal enzymes and phospholipid during dehardening in stem bark of black locust. Plant Physiol., 57: 710-715 